\title{
INFLUENCE OF SOCIAL MEDIA MARKETING ON CONSUMER ENGAGEMENT TOWARDS DURABLE PRODUCTS
}

\author{
Dr. P. Balathandayutham ${ }^{1 凶}$, Dr. K. Anandanatarajan ${ }^{2}$ \\ ${ }^{1}$ Assistant Professor, Business Administration, Government Arts and Science College, Valparia, \\ Tamil Nadu \\ ${ }^{2}$ Associated Professor, Business Administration, Annamalai University, Tamil Nadu
}

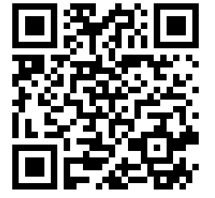

DOI: https://doi.org/10.29121/granthaalayah.v8.i7.2020.787

Article Type: Research Article

Article Citation: Dr. P.

Balathandayutham, and Dr. K. Anandanatarajan. (2020).

INFLUENCE OF SOCIAL MEDIA

MARKETING ON CONSUMER

ENGAGEMENT TOWARDS

DURABLE PRODUCTS. International

Journal of Research -

GRANTHAALAYAH, 8(7), 335-339.

https://doi.org/10.29121/granthaa

layah.v8.i7.2020.787

Received Date: 15 July 2020

Accepted Date: 31 July 2020

Keywords:

Social Media Marketing

Consumer Engagement

\begin{abstract}
The purpose of this paper is to explore the impact of marketing through social media on consumer engagement. The sample population consisted of the online purchasers through a leading website of Chennai, for the previous 5 years. The respondents so selected for the study were asked to explain which type of postings on the websites made them to purchase through online, which of the factors made them to take part in online purchase and also to explore if these features have an influence over their purchase behaviours. The respondents of the study were selected through convenience sampling methods and the sample size was 100 . The data was collected using a questionnaire and the analysis was executed through regression. The results of the study revealed that all the statements of social media marketing have positive relationship with consumer engagement. Except second factor "The privacy of the consumers who use the product is maintained." all other factors are highly significant with consumer engagement which means social media marketing have strong relationship with consumer engagement.
\end{abstract}

\section{INTRODUCTION}

SMM (Social media marketing) is kind of marketing through internet. It is a method which uses websites of social networking for marketing the products and services. The goal of marketing of this type is to establish the contentment of consumers so that they will subsequently share it to their friends in social network which ultimately facilitates an organization to enhance the exposure for a brand and widen the reach of the product to customers.

Schultz and Peltier (2013) had stated that the term "consumer engagement" is an indefinable variable. The author had also stated that the marketers and the researchers should make a clear definition of the concept. to be specific the author had also said that engagement can be understood in the light of related concepts like relationship marketing, brand loyalty, marketing orientation, concentric marketing social networks and management of customer relationships. Hollebeek et al. (2014) had brought all these features under one heading in the context of consumers. 
Influence of Social Media Marketing on Consumer Engagement Towards Durable Products

\subsection{PREVIOUS EVIDENCE}

Many research have carried out about the Consumer perception dimension (C Magesh, K Tamizhjyothi, K Anandanatarajan, 2013; C Suresh, K Anandanatarajan, R Sritharan, 2015; C Suresh, K Tamizhjyothi, K Anandanatarajan, 2013; C. Suresh, K.Anandanatarajan, 2015; DCM C.Suresh, K.Anandanatarajan, 2015, DKR. M.Kumaran, K. Anandanatarajan 2015; K Anandanatarajan, 2017; M.Kumaran, , Anandanatarajan K, 2016; Suresh, C., K.Anandanatarajan., 2014), online purchase (RR Kumaran M, Anandanatarajan K., 2016; Srivastava, S., Jacob Mathew Pulikotil, K.Anandanatarajan., 2013 ), social networking sites (DSS Jacob Mathew Pulikotil, Dr.K.Anandanatarajan 2014: DSS Jacob Mathew Pulikotil, K.Anandanatarajan 2014; DSS Jacob Mathew Pulikottil,.K.Anandanatarajan 2013; Jacob mathew Pulikotil, K Anandanatarajan, 2012; Jacob mathew Pulikotil, K Anandanatarajan, S Srivastava 2013; Jacob mathew Pulikotil, K Anandanatarajan, S Srivastava 2013; Jacob Mathew Pulikottil, K.Anandanatarajan 2013), digital marketing (Jayadurga,K., Anandanatarajan, K., 2020; P.Balathandayutham., K. Anandanatarajan., 2020), price perception (P. Balathandayutham, K Anandanatarajan, 2019).

\section{STATEMENT OF THE PROBLEM}

Marketing professionals of the modern times has considered this social media concept as an important element of communication mix in their practices of (IMC) integrated marketing communication. Most of the organizations of the modern days are making communications with heir stakeholders by making use of twitter handle, YOUTUBE videos and FACEBOOK fan page.

The customers are also joining with the social media interactions made by the brand. If they like the contents of a brand, they share it and express their feedback through their views, happiness, dissatisfaction and opinions. Marketing through social media is also faced with certain challenges. These challenges may include the way of assessing the efficiency of marketing through social media and the way through which the engagement of consumers can be enhanced.

\section{NEED FOR THE STUDY}

The last decade had experienced many studies that had been done regarding customer engagement and marketing through social media and nowadays these researchers are being done extensively. These studies prove the fact that significant researches have to be done to explore the various elements of the term customer engagement.

\section{OBJECTIVE OF THE STUDY}

The purpose of this paper was to investigate the impact of social media on the enhancement of customer engagement.

\subsection{REVIEW OF LITERATURE}

Bashar, Abu \& Ahmad, Irshad \&Wasiq, Mohammad (2012); the present day is the world of technology. The marketers and the entrepreneurs have to keep in pace with the changes in the technological advancements. The traditional method of marketing is outdated and they are not useful for marketing the products in the current scenario. The most important element of the current day's marketing and promotion mix is the social media. One of the important methods through which the business people market their products is through social networking sites. This is followed in particular among the handicrafts and fashion products. The authors of this paper had made practical study to apprehend the efficiency of social media as a tool for marketing. The study had also analyzed the level to which social media facilitates the decision-making process of the consumers in purchasing a product.

Farook, Fathima \&Abeysekera, Nalin (2016); the current research study had investigated the impact of social media marketing on the customer engagement. The organizations are continually spending on the technique to market their products online, but in the same way, it is a big challenge for the marketers to assess its effectiveness. Social media marketing helps to bring about two-way communications between the marketers and the customers. 
The respondents of this study consisted of the fans of a FACEBOOK brand site. They were given questionnaires to get responses from them. The findings of the study showed that there was a positive relation of media $\&$ the type of posts with the online engagement of the customers.

Barger, Victor \& Peltier, James \& Schultz, Don (2016); the main aim of this paper was to review the previous studies on the customer engagement. The authors had reviewed the studies done on social media and focussed on the customer engagement which was the main area of study of Schultz and Peltier (2013). It was found that, there is a lack of studies done regarding social media and customer engagement. So, it becomes difficult for the practitioners to look into the enhancement of the concept. The study done by these authors had offered a framework to future researchers about the antecedents as well as the consequences of the customer engagement.

\section{RESEARCH METHODOLOGY}

The sample population consisted of the online purchasers through a leading website of Chennai, for the previous 5 years in Chennai. The respondents so selected for the study were asked to explain which type of postings on the websites made them to purchase through online, which of the factors made them to take part in online purchase and also to explore if these features have an influence over their purchase behaviours. The sample size was 100 and the respondents were selected through convenience sampling.

\subsection{INFLUENCE OF SOCIAL MEDIA MARKETING ON THE CONSUMER ENGAGEMENT}

\begin{tabular}{|c|c|c|c|c|}
\hline \multicolumn{5}{|c}{ Model Summary } \\
\hline R & R Square & Adjusted R Square & F & Sig. \\
\hline $.847(a)$ & .718 & .706 & 60.457 & $.000(\mathrm{a})$ \\
\hline
\end{tabular}

a. Predictors: (Constant), Social media marketing

\section{Coefficients}

\begin{tabular}{|c|c|c|c|c|c|}
\hline & \multicolumn{2}{|c|}{ Unstandardized Coefficients } & \multirow{2}{*}{$\frac{\text { Standardized Coefficients }}{\text { Beta }}$} & \multirow[t]{2}{*}{$\mathrm{t}$} & \multirow[t]{2}{*}{ Sig. } \\
\hline & B & Std. Error & & & \\
\hline (Constant) & 1.101 & .176 & & 6.267 & .000 \\
\hline $\begin{array}{l}\text { The information given about the } \\
\text { product is trustworthy. }\end{array}$ & .100 & .042 & .172 & 2.414 & .018 \\
\hline $\begin{array}{l}\text { The privacy of the consumers who } \\
\text { use the product is maintained. }\end{array}$ & -.066 & .038 & -.124 & $\begin{array}{c}- \\
1.712 \\
\end{array}$ & .090 \\
\hline $\begin{array}{l}\text { The product data on the networking } \\
\text { sites are reliable. }\end{array}$ & .416 & .045 & .588 & 9.332 & .000 \\
\hline $\begin{array}{l}\text { The usage of social media improves } \\
\text { the awareness of a product }\end{array}$ & .257 & .041 & .393 & 6.218 & .000 \\
\hline
\end{tabular}

a. Dependent Variable: Consumer engagement

The above table explains the regression analysis for overall consumer engagement as the dependant variable and various factors of social media marketing as independent variable. For identifying which factor of social media marketing influences predominantly the overall consumer engagment, an analysis of multiple regression was executed and the findings are displayed in the aforesaid table.

The coefficient of Regression determination $\left(\mathrm{R}^{2}\right)$ is 0.718 which connotes that 71.8 percent of the difference on overall consumer engagement is established by the independent variables. In order to verify the significance of $R^{2}$, ANOVA was carried out and the outcome demonstrates a significant result $(F=60.457 ; p<0.000)$ which indicates that the factors of social media marketing considerably have an influence on the overall consumer engagement. All the statements of social media marketing have positive relationship with consumer engagement. Except second factor "The privacy of the consumers who use the product is maintained." all other factors are highly significant with consumer engagement which means social media marketing have strong relationship with consumer engagement. 


\section{CONCLUSION}

The research analysis of the present paper was done by using the FACEBOOK social media method. This media was selected because it is the most famous mode and is highly made use by the marketers as well as the customers. The engagement of the customers is positively related with a lot more number of constructs like trust, satisfaction, loyalty and affective commitment (Brodie et al., 2011). The results of the study revealed that all the statements of social media marketing have positive relationship with consumer engagement. Except second factor "The privacy of the consumers who use the product is maintained." all other factors are highly significant with consumer engagement which means social media marketing have strong relationship with consumer engagement.

\section{SOURCES OF FUNDING}

This research received no specific grant from any funding agency in the public, commercial, or not-for-profit sectors.

\section{CONFLICT OF INTEREST}

The author have declared that no competing interests exist.

\section{ACKNOWLEDGMENT}

None.

\section{REFERENCES}

[1] C Magesh, K Tamizhjyothi, K Anandanatarajan, (2013), Consumer Preference Towards Different Types of Advertisements in Social Networking Sites, NISMA Journal of Management, 226-235

[2] C Suresh, K Anandanatarajan, R Sritharan, (2015), Effect of sales promotion tools on customer purchase decision with special reference to specialty product (camera) at chennai, tamilnadu, Asia Pacific Journal of Research Vol: I. Issue XXI

[3] C Suresh, K Tamizhjyothi, K Anandanatarajan, (2013), Consumer's evaluation towards bundle offers with special reference to FMCG products, International Journal of Recent Scientific Research 5 (Academic issue), $2112 \ldots$

[4] C. Suresh, K.Anandanatarajan (2015) “Consumer evaluation of Sales Promotion Schemes: A Study of Bath Soap in Chidambaram", Annamalai International Journal of Business Studies And Research 1

[5] DCM C.Suresh, K.Anandanatarajan, (2015), "Demographic Analysis of Consumer evaluation towards sales promotion" Internation Journal of Business Intelligence and Innovation 3 (2), 8 - 14

[6] DKR. M.Kumaran, K. Anandanatarajan (2015), "An analysis of perceived risks affecting online purchase intention", Global Journal of Business Management Research 3 (4), 112 - 116

[7] DSS Jacob Mathew Pulikotil, Dr.K.Anandanatarajan (2014), "Good governance through Social networking", International Journal of Business Intelligence And Innovation 2 (1), 139 - 146

[8] DSS Jacob Mathew Pulikotil, K.Anandanatarajan (2014), "'Social networking sites for Hr Recruitment". Caarmel Journal of Management Research 2 (1), 50 - 59

[9] DSS Jacob Mathew Pulikottil,.K.Anandanatarajan (2013),"The role of social media in networking among HR professionals", Protsahan A Journal To Encourage Young Researchers 1 (1), 435 - 442

[10] Jacob mathew Pulikotil, K Anandanatarajan, (2012), A study on social networking and relationship among university students, Holy Grace Management Review 4 (1), 53 - 60

[11] Jacob mathew Pulikotil, K Anandanatarajan, S Srivastava (2013), "Social Networking among HR Professionals"

[12] Jacob mathew Pulikotil, K Anandanatarajan, S Srivastava (2013), "The effect of using social networking sites in office on the job performance of IT professionals", Holy Grace Management Review 5 (1), 136 - 149

[13] Jacob Mathew Pulikottil, K.Anandanatarajan (2013),"Advertising through Social networks prospects and problems" Research Explorer 2 (Special), 73 - 74 
[14] Jayadurga,K., Anandanatarajan, K., (2020) Effect of Digital Marketing on Brand Loyalty: A Study Conducted Among Students , Alochana Chakra Journal, 5204-5210

[15] K Anandanatarajan, (2017), Customer Relationship Management - A Strategic Tool for Marketing, International Journal of Research and Analytical Reviews 4 (1), 996-1002

[16] M.Kumaran, , Anandanatarajan K, (2016), Consumer life style and online shopping continuance intention: An emphirical study of Chennai Consumers, Annamalai University Humanities Journal 50 (1), 269 - 276

[17] P. Balathandayutham and R. Sritharan; service quality survey in apartment industry: a study on residential satisfaction among urban residents, in IISRO Multi conferences proceeding, 2013

[18] P. Balathandayutham, K . Anandanatarajan (2019), “Influence Of Job Characteristic's Construct On Job Performance Among The Employees Of Restaurants". Restaurant Business 118 (9), 334 - 340

[19] P. Balathandayutham, K Anandanatarajan (2019) Price and Green Attitude Towards Environmental Friendly Product in Chidambaram, Review of Research Journal, Special Issue Volume 1 November 2019, 226-231

[20] P.Balathandayutham and K. Anandanatarajan (2020), Digital marketing through social networking sites (SNS): A field of digital empowerment, International Journal of Scientific \& Technology Research volume 9, issue 02, February 2020. 734-736

[21] RR Kumaran M, Anandanatarajan K (2016), An empirical study on the impact of risk perception on 'online purchase intention' , international journal of recent scientific research 7 (6), 11990 - 11993

[22] Srivastava, S., Jacob Mathew Pulikotil, K.Anandanatarajan (2013), "Home schooling through Social networking sites" Sodh Pioneer Journal of IT And Management 9 (2), 64 - 69

[23] Suresh, C., K.Anandanatarajan (2014), "A study on Customer perception on store brand product with special reference to Chennai residents", M - Infinity Journal of Management 1 (3), 14 - 17

[24] Bashar, Abu \& Ahmad, Irshad \&Wasiq, Mohammad. (2012). Effectiveness of Social Media As A Marketing Tool: An Empirical Study. International Journal of Marketing, Financial Services \& Management Research.

[25] Farook, Fathima \&Abeysekera, Nalin. (2016). Influence of Social Media Marketing on Customer Engagement. International Journal of Business and Management Invention. 5. 2319-8028.

[26] Barger, Victor \& Peltier, James \& Schultz, Don. (2016). Social media and consumer engagement: A review and research agenda. Journal of Research in Interactive Marketing. 10. 268-287. 10.1108/JRIM-06-2016-0065. 